\title{
Polymorphism in the melatonin receptor gene in buffalo populations of the Brazilian Amazon - Genet. Mol. Res. 15 (2): gmr.15027960
}

Published online: April 27, 2016 (DOI: 10.4238/gmr.15027960)

Corrected after publication: May 20, 2016

(DOI: 10.4238/gmr.150279601)

The correction is only in the name of the first author and should be:

E.M. Barbosa ${ }^{1}$, B.B. Souza ${ }^{2}$, R.C. Guimarães ${ }^{2}$ J.S.N. Azevedo ${ }^{3}$, E.C. Gonçalves ${ }^{4}$, H.F.L. Ribeiro ${ }^{2}$, S.T. Rolim Filho ${ }^{2}$ and E. Silva Filho ${ }^{2}$ 